○佐川賢, 清水曹, 保田真也。 山下由已男，荒居廣

(製品科学研究所，人间工学部)

\title{
1.はじめに
}

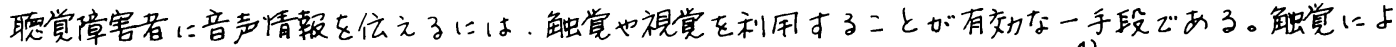

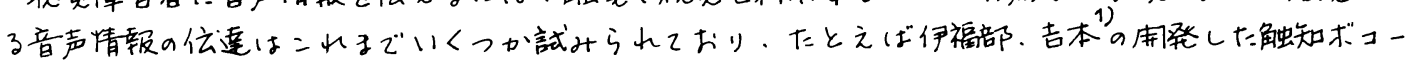
ダーでは、音声を16a周波数带に分十各々の音の強きを一次元の振動子アレイに表示し指先で諰識き せている。しかし一次元、振動子アレイでは伝连きれる情報量に制限があり、特に話しことばの認誡

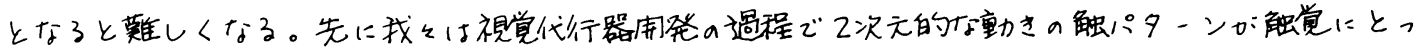
て非常に認裁しやすいものであることを示しだ)。そ二で今回二の呈示方法を用いて音声を乙次元的 に表示し、音声、特に話しことばを認識させる機を用発した。音声のて次元表記法としてはフォル

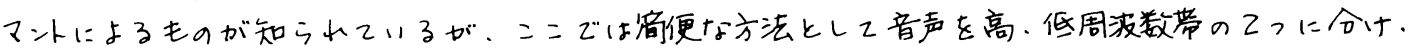
各々に零交叉法を適用して特街的な周波数成分を捕え、そ小を入Y軸の乙次元に表記する方法を採用 した。また触刺激としては当研究室で周発した超小型ソレノイド素子を用いだ、本報告では装置の概 要とそれを用、て行った音声、認識实験の結果を報告する。

\section{2. 装置a概要}

Fig. 1 は装置全体のブロックダイヤブラムを示す。マイクで受けた音声はおよそ750 Hz を境とレ

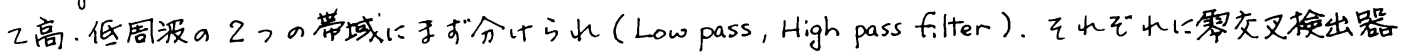
(Zero crossing detector) を用いてそれぞれの周波数带にある最大强度にほぼ近い周波数を捕える。

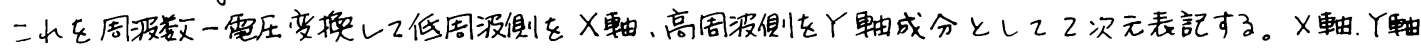
はそれぞれ7分割、9分割されており、結局 $7 \times 9$ のマトリッフスの一点に音声が表示される。この マトリックスは同しく7×9の触覚ディスプレイ(Tactile display)に対㐫し、乙次元的な触賞制淂を 与える。触覚ディスプレイは超小型ソレ/イド触針を7 $\mathrm{mm}$ 间隔で並べて作られ、各触針はおよそ

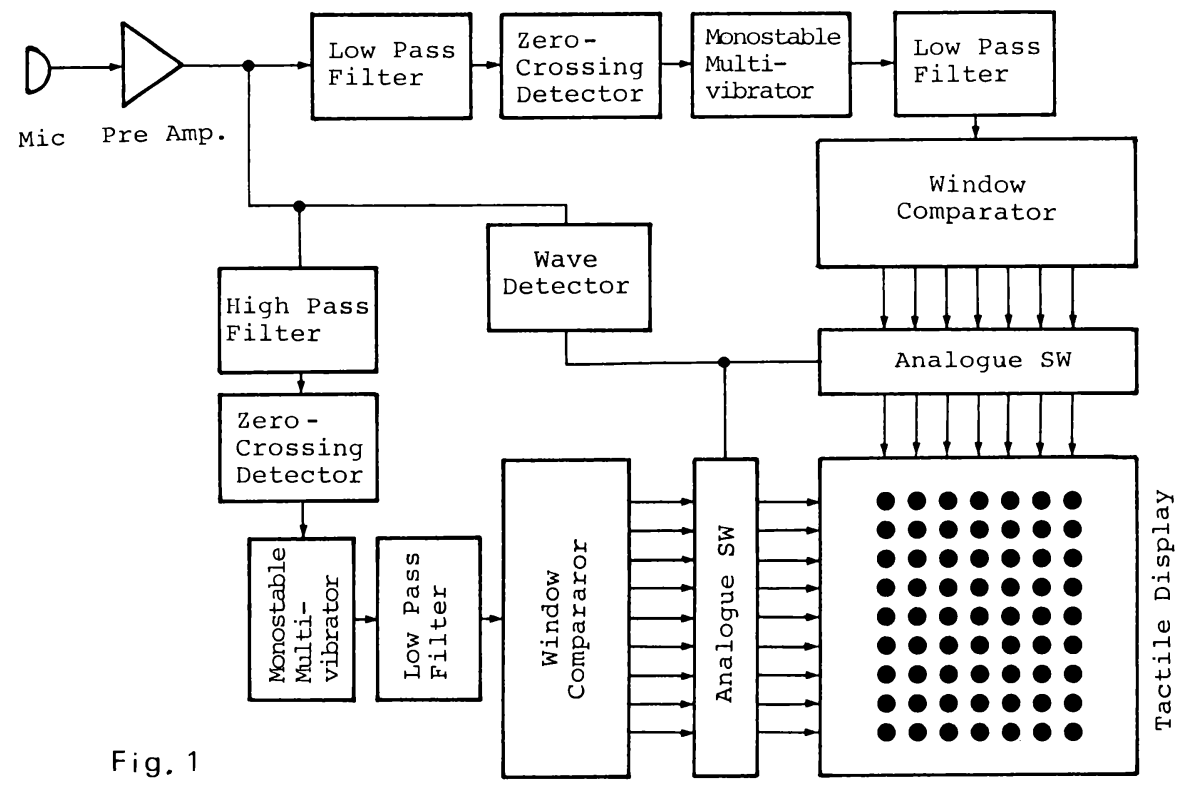




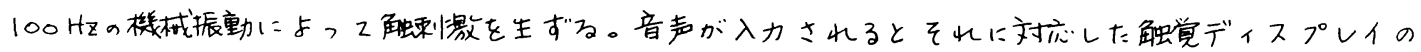
一点が駆動され、音声が变化すればその点は次々と位置を变え動きをもった触賞のパターンが得られ る。Fig. 2 に特徵的なパターンの例を示す。触觉ディスプレイの大ききはおよそ $5 \mathrm{~cm} \times 7 \mathrm{~cm}$ で、手、 平で触れて刺撒を感ずる。㙂賞障害者はことはに特有な触パターンを学習することによって音声を認 識する。

\section{3 音声 認識実験}

本装置による音声の認識を調べるため。まず办音の 識别を行った。百学た訓練で触パターンを学翼した後。 母音を通常の発声スピードでランダムに250回呈示レ その反㐫を承めた。Table 1 にそa䊅果を示す。呈示 した制激に对して被験者がどン答えたかをパーセント

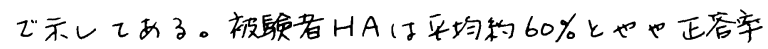
が低いがKS、場合は95\%とには完全に認識でるて 11る。Table $2(a)(b)$ は常用語5つのセットを2つ
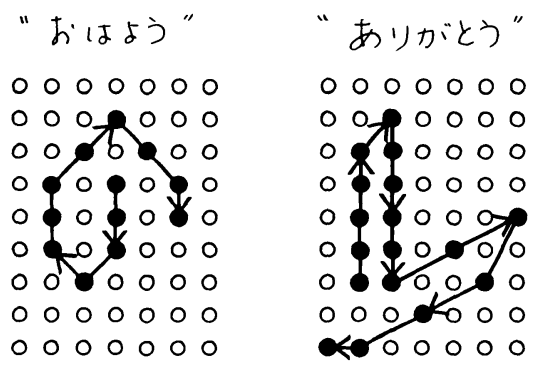

Fig. 2

用い乙同椂の誡别宝豎を行った結果である。(a)のセット ではHAの゙ミようなら”を除いて正荅率はすべて70\% 以上となっている。また（b）のセットでKS、場合は は1゙90\%近、正答率を示している。实験を重ねるごと に正答率が上界しているところから、今後訓綶を重小 ればかなり高い正答率が得られると考之られる。冊音 と峃語の繥果を比㜞してみると、学語の埸合それはど 正答率は落らておらす”。むい被駼者HA、埸合など は上がることもあるので、話しことばの認識にとって 本装置は有用であると思われる。

$$
\text { 文献 }
$$

1) Ifukube, $T$. and

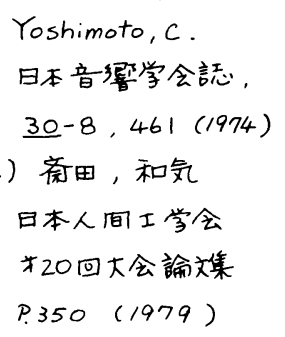

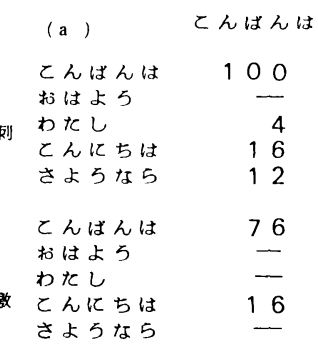

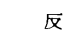

扣はよ 5

$$
\frac{88}{28}
$$$$
\frac{100}{8}
$$

反

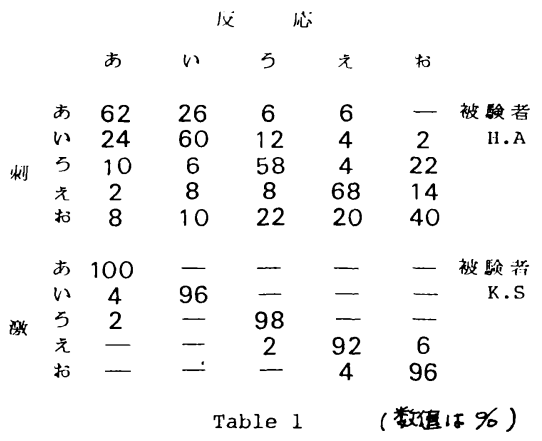

応 (b)

ありがと すみません 刺扔かあさん 扣とらさん たたいま

ありがとう すみません

おかあさん 扎と 5 さ た塻いま
ありがとらすみません执かあさん 心 打とらさんたたいま

$\begin{array}{rrr}68 & 16 & 4 \\ 12 & 60 & 46 \\ 4 & -12 & 12 \\ 16 & 16 & 32 \\ 4 & 4 & - \\ 96 & 8 & 92 \\ 4 & - & 12\end{array}$

$\begin{array}{rrc}1 & 2 & \text { 被颐者 } \\ 1 & 2 & \text { H.A } \\ 2 & 4 & \\ 8 & \\ 4 & 0 & \end{array}$

被臥者 K.S 